\title{
A New Antifungal Phenolic Glycoside Derivative, Iridoids and Lignans from Alibertia sessilis (Vell.) K. Schum. (Rubiaceae)
}

\author{
Viviane C. da Silva, ${ }^{a}$ Vanderlan da S. Bolzani, ${ }^{a}$ Maria C. M. Young ${ }^{b}$ and Márcia N. Lopes *,a \\ ${ }^{a}$ Departamento de Química Orgânica, Instituto de Química, Universidade Estadual Paulista, CP 355, \\ 14801-970 Araraquara-SP, Brazil \\ ${ }^{b}$ Seção de Fisiologia e Bioquímica de Plantas, Instituto de Botânica, CP 4005, \\ 01061-970 São Paulo-SP, Brazil
}

\begin{abstract}
Um novo derivado fenólico glucosilado antifúngico, 3,4,5-trimetoxifenil-1-O- $\beta$-D-(5-Osiringoila)-apiofuranosil- $(1 \rightarrow 6)-\beta$-D-glicopiranosideo $(\mathbf{1})$, juntamente com quatro iridóides conhecidos, ácido geniposídico (2), geniposídeo (3), 6 $\alpha$-hidroxigeniposideo (4) e $6 \beta$ hidroxigeniposideo (5); duas lignanas, (+)-lioniresinol-3 $\alpha-O-\beta$-D-glicopiranosideo (6), (-)lioniresinol-3 $\alpha-O-\beta$-D-glicopiranosideo (7); e dois ácidos fenólicos, ácidos clorogênico (8) e salicílico (9) e D-manitol (10), foram isolados do extrato etanólico dos galhos de Alibertia sessilis. As estruturas de $\mathbf{1}$ e dos compostos conhecidos foram determinadas por análise espectroscópica. Todos os compostos isolados foram avaliados quanto à atividade antifúngica frente aos dois fungos fitopatogênicos Cladosporium cladosporioides e C. sphaerospermum por bioautografia direta.
\end{abstract}

A new antifungal phenolic glycoside, 3,4,5-trimethoxyphenyl-1-O- $\beta$-D-(5-O-syringoyl)apiofuranosyl-( $1 \rightarrow 6)-\beta$-D-glucopyranoside $(\mathbf{1})$, together with four known iridoids, geniposidic acid (2), geniposide (3), 6 $\alpha$-hydroxygeniposide (4) and 6 $\beta$-hydroxygeniposide (5); two lignans, (+)-lyoniresinol-3 $\alpha-O-\beta$-D-glucopyranoside (6), (-)-lyoniresinol-3 $\alpha-O-\beta$-D-glucopyranoside (7); and two phenolic acids, chlorogenic (8) and salicylic acids $(\mathbf{9})$ and D-manitol (10), were isolated from the ethanolic extract of the stems of Alibertia sessilis. Structures of $\mathbf{1}$ and of the known compounds were determined by spectroscopic analysis. All compounds isolated were evaluated for their antifungal activities against two phytopathogenic fungi strains Cladosporium cladosporioides and C. sphaerospermum by direct bioautography.

Keywords: Rubiaceae, Alibertia sessilis, phenolics, iridoids, antifungal

\section{Introduction}

In our continuing search for antifungal agents from plants from the Cerrado and Atlantic Forest in the State of São Paulo, Brazil, we screened several species of the Rubiaceae family, which is recognized as a rich source of bioactive metabolites. ${ }^{1-5}$ We particularly studied plants of the Alibertia genus, since relatively few chemical studies have been reported. Our previous investigation with the leaves of $A$. macrophylla resulted in the isolation of antifungal iridoid aglycones, and caffeic acid ester derivatives. ${ }^{6,7}$ Additionally, flavones and coumarin have been reported for A. myrciifolia. ${ }^{8}$

This paper reports the bioassay-guided isolation and structure elucidation of the new 3,4,5-trimethoxyphenyl-1-

*e-mail: mnlopes@iq.unesp.br
$O$ - $\beta$-D-(5-O-syringoyl)-apiofuranosyl-( $1 \rightarrow 6)-\beta$-D-glucopyranoside (1) (Figure 1), and the known lignans $(+)-$ lyoniresinol-3 $\alpha-O-\beta$-D-glucopyranoside (6), (-)-lyoniresinol$3 \alpha-O-\beta$-D-glucopyranoside (7), which are being described for the first time for Rubiaceae. This paper also reports the isolation of iridoids geniposidic acid (2), geniposide (3), $6 \alpha-$ hydroxygeniposide (4) and 6ß-hydroxygeniposide (5), phenolic acids, chlorogenic (8) and salicylic acid (9) and D-manitol (10). The antifungal activity of compound 1 against Cladosporium sphaerospermum and C. cladosporioides was detected by using direct bioautography.

\section{Results and Discussion}

The antifungal ethanol extract from Alibertia sessilis stems was partitioned with hexane, ethyl acetate and $n$ - 


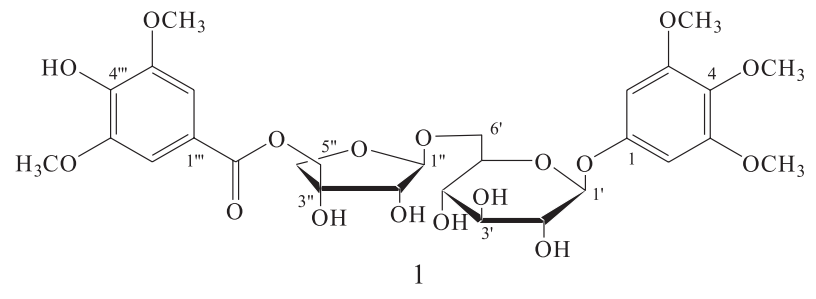

Figure 1. Phenolic glycoside isolated from Alibertia sessilis.

butanol. These sub-extracts were tested against Cladosporium sphaerospermum and C. cladosporioides using direct bioautography showing that only the ethyl acetate fraction was active. This sub-extract was bioassayguide fractioned to afford a new phenolic derivative $\mathbf{1}$ along with several known compounds.

Compound 1 was isolated as a brown amorphous powder. The molecular formula was determined as being $\mathrm{C}_{29} \mathrm{H}_{38} \mathrm{O}_{17}$ from the HRESIMS at $\mathrm{m} / z 657.2065$ $[\mathrm{M}-\mathrm{H}]^{-}$. The UV spectrum showed an absorption maximum at $279 \mathrm{~nm}$, which is compatible with a phenolic structure. The IR spectrum showed a characteristic absorption band attributable to the following groups: carbonyl $\left(1708 \mathrm{~cm}^{-1}\right)$, hydroxyl $\left(3418 \mathrm{~cm}^{-1}\right)$, and aromatic (1605 and $\left.1509 \mathrm{~cm}^{-1}\right)$, as well as a glycosidic linkage $\left(1063 \mathrm{~cm}^{-1}\right)$. The ${ }^{1} \mathrm{H}$ and ${ }^{13} \mathrm{C}$ NMR spectra (Table 1) revealed signals for two 1,3,4,5-tetrasubstituted symmetrical aromatic rings. The ${ }^{1} \mathrm{H}$ NMR exhibited singlet signals corresponding to five aromatic methoxyls at $\delta_{\mathrm{H}} 3.77\left(6 \mathrm{H}, \mathrm{OCH}_{3}-3,5\right)$, $3.68\left(3 \mathrm{H}, \mathrm{OCH}_{3}-4\right)$, and $3.87\left(6 \mathrm{H}, \mathrm{OCH}_{3}-3^{\prime \prime \prime}, 5^{\prime \prime \prime}\right)$ and two sets of aromatic proton signals at $\delta_{\mathrm{H}} 6.41(2 \mathrm{H}, \mathrm{H}-$ $2,6)$ and $7.34\left(2 \mathrm{H}, \mathrm{H}-2^{\prime \prime \prime}, 6^{\prime \prime \prime}\right)$ due to a 3,4,5-trimethoxy phenyl derivative and symmetrical 3,5-dimethoxy-4hydroxy-benzoyl moieties, respectively. ${ }^{9}$ This was supported by the $g \mathrm{HMBC}$ spectrum, which showed cross-peaks corresponding to a long-range coupling of hydrogen at $\delta_{\mathrm{H}} 6.41$ and carbon signals at $\delta_{\mathrm{C}} 155.9$ (C-1), 154.7 (C-3,5), 134.7 (C-4) and 96.5 (C-2,6) and also between hydrogen at $\delta_{\mathrm{H}} 7.34$ and carbon signals at $\delta_{\mathrm{C}} 167.9(\mathrm{C}=\mathrm{O}), 149.1\left(\mathrm{C}-3^{\prime \prime \prime}, 5^{\prime \prime \prime}\right), 143.1\left(\mathrm{C}-4^{\prime \prime \prime}\right)$, $120.6\left(\mathrm{C}-1^{\prime \prime \prime}\right)$ and $108.5\left(\mathrm{C}-2^{\prime \prime \prime}, 6^{\prime \prime \prime}\right)$. Others signals observed in ${ }^{1} \mathrm{H}$ and ${ }^{13} \mathrm{C}$ NMR spectra are consistent with glycosyl moieties. According to literature,$^{10}$ the comparison of the ${ }^{13} \mathrm{C}$ NMR data of the glycosidic moiety of various other analogous compounds, the structure of 1 seems to be composed of a glucosyl [ $\delta_{\mathrm{C}}$ $103.2\left(\mathrm{C}-1^{\prime}\right), 74.9$ (C-2'), 77.9 (C-3'), 71.5 (C-4'), 76.9 $\left(\mathrm{C}-5^{\prime}\right)$ and $\left.68.2\left(\mathrm{C}-6^{\prime}\right)\right]$ and an apiosyl $\left[\delta_{\mathrm{C}} 110.4(\mathrm{C}-\right.$ $\left.1^{\prime \prime}\right), 78.7$ (C-2"), 79.0 (C-3"), 75.0 (C-4") and 67.9 $\left.\left(\mathrm{C}-6^{\prime \prime}\right)\right]$ moieties. The ${ }^{1} \mathrm{H},{ }^{13} \mathrm{C}$ NMR and TOCSY spectra confirmed the presence of these two sugar moieties due to the presence of two anomeric signals at $\delta_{\mathrm{H}} 4.79$ $(\mathrm{d}, J 7.5 \mathrm{~Hz}) / \delta_{\mathrm{C}} 103.2(\mathrm{CH})$ for glucose and $\delta_{\mathrm{H}} 5.01$ $(\mathrm{d}, J 2.3 \mathrm{~Hz}) / \delta_{\mathrm{C}} 110.4(\mathrm{CH})$ for apiose. Furthermore, the coupling constants $J 7.5 \mathrm{~Hz}$ of the anomeric proton signal of the D-glucosyl moiety as well as the chemical shift $\left(\delta_{\mathrm{C}} 110.4\right)$ of the anomeric carbon of the D-apiosyl moiety, demonstrated that both sugar moieties have $\beta$-anomeric configurations. The $g \mathrm{HMBC}$ spectrum of 1 revealed cross-peaks corresponding to long-range couplings of hydrogens H- $6^{\prime}$ of $\beta$-glucose at $\delta_{\mathrm{H}} 3.63$ $(\mathrm{d}, J 10.0 \mathrm{~Hz})$ and $4.06(\mathrm{~d}, J 10.0 \mathrm{~Hz})$ and carbon C1 " of apiose at $\delta_{\mathrm{C}} 110.4$; in this way, the $\beta$-D-apiosyl moiety was attached to C- $6^{\prime}$ of the glucose. The chemical shift of the oxymethylene carbon C- $6^{\prime}\left(\delta_{\mathrm{C}}\right.$ 68.2) was used to confirm the disaccharide linkage as apiofuranosyl-( $(1 \rightarrow 6)$-glucopyranoside. ${ }^{10}$ In addition, long-range correlations between $\mathrm{H}-5^{\prime \prime}$ signals of $\beta$-Dapiose $\left[\delta_{\mathrm{H}} 4.31(\mathrm{~d}, J 11.4 \mathrm{~Hz})\right.$ and $\left.4.39(\mathrm{~d}, J 11.4 \mathrm{~Hz})\right]$ and the syringoyl carbonyl group $\left(\delta_{\mathrm{C}} 167.9\right)$ indicated that the 3,5-dimethoxy-4-hydroxy-benzoyl group was attached to C- $5^{\prime \prime}$ of the $\beta$-D-apiose. Finally, the proton at $\delta_{\mathrm{H}} 4.79\left(\mathrm{H}-1^{\prime}\right.$ of glucose) was correlated with $\mathrm{C}-1$ of the 3,4,5-trimethoxy phenyl group $\left(\delta_{\mathrm{C}}\right.$ 155.9), indicating that the $\beta$-D-glucosyl moiety was located at $\mathrm{C}-1$. Therefore, the structure of compound $\mathbf{1}$ was established as being 3,4,5-trimethoxyphenyl-1-O- $\beta$-D(5- $O$-syringoyl)-apiofuranosyl-( $(1 \rightarrow 6)$ - $\beta$-D-glucopyranoside.

The known compounds $\mathbf{2 - 1 0}$ were identified by comparing their ${ }^{1} \mathrm{H}$ and ${ }^{13} \mathrm{C}$ NMR data with those previously published in literature. ${ }^{11-16}$

The antifungal activity of compounds 1, 2, 6-10 against Cladosporium cladosporioides and C. sphaerospermum was evaluated by direct bioautography on a TLC plate. ${ }^{17,18}$ Only compound 1 exhibited moderate activity (MIC of $100 \mu \mathrm{g}$ ), when compared with the standard nystatin $(1.0 \mu \mathrm{g})$.

\section{Experimental}

\section{General experimental procedures}

1D- $\left({ }^{1} \mathrm{H},{ }^{13} \mathrm{C}, \mathrm{TOCSY}\right)$ and 2D- (gHMQC and $\left.g \mathrm{HMBC}\right)$ NMR experiments were recorded on a Varian INOVA 500 spectrometer $(11.7 \mathrm{~T})$ at $500 \mathrm{MHz}\left({ }^{1} \mathrm{H}\right)$ and $126 \mathrm{MHz}$ $\left({ }^{13} \mathrm{C}\right)$, using adequate solvent with TMS as internal standard. Accurate-mass measurements were performed on a quadrupole-time of flight instrument (UltrOTOF-Q, Bruker Daltonics). IR spectrum was obtained on a Nicolet730 FT-IR spectrometer using $\mathrm{KBr}$ discs. UV absorption was measured on a Varian ProStar 330 diode array spectrophotometer. Optical rotation was measured on a Polamat A Carl Zeiss Jena. Preparative HPLC was carried 
Table 1. ${ }^{1} \mathrm{H}$ and ${ }^{13} \mathrm{C}$ NMR (500 and $126 \mathrm{MHz}$, respectively; $J$ in $\mathrm{Hz}$ ). and $g \mathrm{HMBC}$ data $\mathbf{1}$ (in $\mathrm{CD}_{3} \mathrm{OD}$ )

\begin{tabular}{|c|c|c|c|}
\hline position & $\delta_{\mathrm{C}}$ & $\delta_{\mathrm{H}}$ & $g \mathrm{HMBC}$ \\
\hline 1 & $155.9(\mathrm{C})$ & - & \\
\hline 2,6 & $96.5(\mathrm{CH})$ & $6.41 \mathrm{~s}$ & $96.5 / 134.7 / 154.7 / 155.9$ \\
\hline 3,5 & 154.7 (C) & - & \\
\hline 4 & 134.7 (C) & - & \\
\hline $1^{\prime}$ & $103.2(\mathrm{CH})$ & $4.79 \mathrm{~d}(7.5)$ & 155.9 \\
\hline $2^{\prime}$ & $74.9(\mathrm{CH})$ & $3.43 \mathrm{~m}$ & 103.2 \\
\hline $3^{\prime}$ & $77.9(\mathrm{CH})$ & $3.52 \mathrm{~m}$ & \\
\hline $4^{\prime}$ & $71.5(\mathrm{CH})$ & $3.34 \mathrm{~m}$ & 77.9 \\
\hline $5^{\prime}$ & $76.9(\mathrm{CH})$ & $3.60 \mathrm{~m}$ & \\
\hline $6^{\prime}$ & $68.2\left(\mathrm{CH}_{2}\right)$ & $3.63 \mathrm{~d}(10.0) / 4.06 \mathrm{~d}(10.0)$ & 71.5/110.4 \\
\hline $1^{\prime \prime}$ & $110.4(\mathrm{CH})$ & $5.01 \mathrm{~d}(2.3)$ & $68.2 / 75.0 / 78.7$ \\
\hline $2^{\prime \prime}$ & $78.7(\mathrm{CH})$ & $3.94 \mathrm{~d}(2.3)$ & \\
\hline $3^{\prime \prime}$ & $79.0(\mathrm{C})$ & - & \\
\hline $4^{\prime \prime}$ & $75.0\left(\mathrm{CH}_{2}\right)$ & $3.85 \mathrm{~m} / 4.08 \mathrm{~d}(9.7)$ & $67.9 / 79.0 / 110.4$ \\
\hline $5^{\prime \prime}$ & $67.9\left(\mathrm{CH}_{2}\right)$ & $4.31 \mathrm{~d}(11.4) / 4.39 \mathrm{~d}(11.4)$ & $75.0 / 78.7 / 79.0 / 167.9$ \\
\hline $1^{\prime \prime \prime}$ & $120.6(\mathrm{C})$ & - & \\
\hline $2^{\prime \prime \prime}, 6^{\prime \prime \prime}$ & $108.5(\mathrm{CH})$ & $7.34 \mathrm{~s}$ & $120.6 / 143.1 / 149.1 / 167.9$ \\
\hline $3^{\prime \prime \prime}, 5^{\prime \prime \prime}$ & $149.1(\mathrm{C})$ & - & \\
\hline $4^{\prime \prime \prime}$ & $143.1(\mathrm{C})$ & - & \\
\hline $\mathrm{C}=\mathrm{O}$ & 167.9 & - & \\
\hline $3,5-\mathrm{OCH}_{3}$ & 56.7 & $3.77 \mathrm{~s}$ & 154.7 \\
\hline $4-\mathrm{OCH}_{3}$ & 61.2 & $3.68 \mathrm{~s}$ & 134.7 \\
\hline $3^{\prime \prime \prime}, 5^{\prime \prime \prime}-\mathrm{OCH}_{3}$ & 56.9 & $3.87 \mathrm{~s}$ & 149.1 \\
\hline
\end{tabular}

out in a Varian HPLC, using a Phenomenex Luna RP18 (2) column $(250 \times 21.20 \mathrm{~mm}$ i.d. $\times 10 \mu \mathrm{m})$.

\section{Plant material}

Alibertia sessilis was collected in the Estação Ecológica e Experimental de Mogi-Guaçu (Ecological and Experimental Reserve of Mogi-Guaçu), São Paulo, Brazil in November 2003 by Dr M.C.M. Young and identified by Dr I. Cordeiro. The voucher specimen (SP 370.914) was deposited at the Botanical Institute Herbarium, São Paulo, Brazil.

\section{Extraction and isolation of constituents}

The dried and powdered stems (50.0 g) of A. sessilis were extracted exhaustively with ethanol, at room temperature, to give a crude material (4.15 g), which was partitioned in hexane, EtOAc and $n$-BuOH. After evaporation, the EtOAc extract (1.30 g) was submitted to column chromatography on Sephadex LH-20 using $\mathrm{MeOH}$ as eluent to give 15 fractions after TLC analysis. Fraction 1 (116.2 mg) was composed of a precipitate, which was recrystalized with $\mathrm{H}_{2} \mathrm{O}$ to give D-manitol (10) (63.7 mg). Fraction 2 (146.4 mg) was subjected to column chromatography on RP-18 using a gradient mixture of $\mathrm{H}_{2} \mathrm{O} / \mathrm{MeOH}$ and $\mathrm{MeOH} / \mathrm{EtOAc}$ as eluent to give 11 subfractions. Subfraction $2.1(80.0 \mathrm{mg})$ was re- chromatographed on $\mathrm{RP}-18$, eluted with $\mathrm{H}_{2} \mathrm{O}$ with increasing amounts of $\mathrm{MeOH}$ to afford geniposidic acid (2) (11.8 mg). Subfraction 2.7 (29.6 mg) was also submitted to column chromatography on RP-18, using a gradient solvent system of $\mathrm{H}_{2} \mathrm{O} / \mathrm{MeOH}$ and $\mathrm{MeOH} /$ EtOAc as eluent to yield 7 subfractions after TLC analysis. Subfraction 2.7 .6 (18.8 mg) was chromatographed by preparative HPLC $\left(\mathrm{C}_{18}\right.$ column; mobile phase:

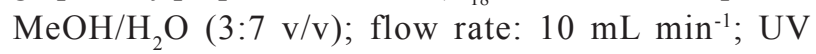
detector: $238 \mathrm{~nm}$ ) to separate the mixture of the diastereoisomeric lignans (+)-lyoniresinol $3 \alpha-O-\beta$-Dglucopyranoside (6) (6.5 mg) and (-)-lyoniresinol $3 \alpha-$ $O$ - $\beta$-D-glucopyranoside (7) $(5.8 \mathrm{mg}) .{ }^{19}$ Subfraction 2.7 .7 $(6.7 \mathrm{mg})$ was identified as 3,4,5-trimethoxyphenyl-1-O$\beta$-D-(5-O-syringoyl)-apiofuranosyl- $(1 \rightarrow 6)-\beta$-D-glucopyranoside (1). Fraction 4 (274.2 $\mathrm{mg}$ ) was fractioned on RP-18 using $\mathrm{H}_{2} \mathrm{O}$ with increasing amounts of $\mathrm{MeOH}$ as mobile phase to give salicylic acid (9) $(6.4 \mathrm{mg})$. Fractions 5 and 6 (104.9 $\mathrm{mg}$ ) were combined and submitted to column chromatography on silica gel eluting with hexane/EtOAc and EtOAc/MeOH to give $6.9 \mathrm{mg}$ of chlorogenic acid (8).

The $n$-butanol extract ( $0.55 \mathrm{~g}$ ) was submitted to column chromatography on Sephadex LH-20 using $\mathrm{MeOH}$ as eluent to give 7 fractions after TLC analysis. Fraction 3 (180.0 mg) was subjected to column chromatography on RP-18 using a gradient mixture of $\mathrm{H}_{2} \mathrm{O} / \mathrm{MeOH}$ to give 9 subfractions. Subfraction $3.4(10.2 \mathrm{mg})$ was identified as 
an iridoid mixture 3-5 and subfraction $3.6(8.6 \mathrm{mg})$ as a lignan mixture 6-7.

3,4,5-trimethoxyphenyl-1-O- $\beta-D-(5-O$-syringoyl)apiofuranosyl- $(1 \rightarrow 6)-\beta$-D-glucopyranoside (1)

Brown amorphous powder $(6.7 \mathrm{mg}, 0.16 \%) .[\alpha]_{\mathrm{D}}^{25}$ -2.36 (c 0.021, MeOH). UV $\lambda_{\max } / \mathrm{nm}(\mathrm{MeOH}) 279$. IR $(\mathrm{KBr}) v_{\max } / \mathrm{cm}^{-1}: 3418,2931,1708,1605,1509,1461$, $1427,1338,1228,1125,1063,816,764$. HRESIMS $m / z$ $657.2065[\mathrm{M}-\mathrm{H}]^{-}$(calcd for $\mathrm{C}_{29} \mathrm{H}_{37} \mathrm{O}_{17}, \mathrm{~m} / z 657.2031[\mathrm{M}$ - $\left.\mathrm{H}]^{-}\right) .{ }^{1} \mathrm{H}$ and ${ }^{13} \mathrm{C}$ NMR: see Table 1 .

\section{Known compounds isolated}

The structures of known compounds were established by ${ }^{1} \mathrm{H}$ and ${ }^{13} \mathrm{C}$ NMR and $g \mathrm{HMBC}$ data and by comparing their spectroscopy data with those reported in literature.

\section{Geniposidic acid (2) (0.28\%)}

The ${ }^{1} \mathrm{H}$ and ${ }^{13} \mathrm{C}$ NMR data, in $\mathrm{CD}_{3} \mathrm{OD}$, were in accordance with those reported in reference 11.

Geniposide (3); 6 $\alpha$-hydroxygeniposide (4); $6 \beta$ hydroxygeniposide (5) (0.24\%)

The ${ }^{1} \mathrm{H}$ and ${ }^{13} \mathrm{C}$ NMR data of the mixture, in $\mathrm{CD}_{3} \mathrm{OD}$, were in accordance with those reported in references 12 and 13 . The compounds were identified in mixture mainly on the basis on their TOCSY spectra.

\section{(+)-Lyoniresinol-3 $\alpha-\mathrm{O}-\beta$-D-glucopyranoside (6) (0.15\%) and (-)-lyoniresinol-3 $\alpha-\mathrm{O}-\beta$-D-glucopyranoside (7) $(0.14 \%)$}

The ${ }^{1} \mathrm{H}$ and ${ }^{13} \mathrm{C}$ NMR data, in $\mathrm{CD}_{3} \mathrm{OD}$, were in accordance with those reported in reference 14 .

\section{Chlorogenic acid (8) (0.16\%)}

The ${ }^{1} \mathrm{H}$ and ${ }^{13} \mathrm{C}$ NMR data, in DMSO- $d_{6}$, were in accordance with those reported in reference 15 .

\section{Salicylic acid (9) (0.15\%)}

The ${ }^{1} \mathrm{H}$ and ${ }^{13} \mathrm{C}$ NMR data, in $\mathrm{CD}_{3} \mathrm{OD}$, were in accordance with those reported in reference 16 .

\section{D-manitol (10) (1.53\%)}

The ${ }^{1} \mathrm{H}$ and ${ }^{13} \mathrm{C}$ NMR data, in $\mathrm{D}_{2} \mathrm{O}$, were in accordance with those reported in reference 16.

\section{Antifungal Assay}

The microorganisms used in the antifungal assays Cladosporium sphaerospermum (Penzig) SPC 491 and $C$. cladosporioides (Fresen) SPC 140 had been kept at the Botanical Institute of São Paulo, Brazil. For the antifungal assay, solutions containing $100,50,25,10,5$ and $1 \mu \mathrm{g}$ of the test compound were prepared. $10.0 \mu \mathrm{L}$ of each solution was applied to pre-coated TLC plates eluted with EtOAc/ $\mathrm{MeOH}(7: 3 \mathrm{v} / \mathrm{v})$ and dried to completely remove all solvents. The chromatograms were sprayed with a spore suspension of Cladosporium sphaerospermum or C. cladosporioides in glucose and salt solution and incubated for $72 \mathrm{~h}$ in darkness in a moistened chamber at $25^{\circ} \mathrm{C}$. A clear inhibition zone appeared against a dark background indicating the minimal amount of the compound required to eliminate the fungus (detection limits - minimum amount required for the inhibition of fungal growth on TLC plates). Nystatin was used as the positive control $(1 \mu \mathrm{g}){ }^{17,18}$

\section{Conclusions}

Lignans $\mathbf{6}$ and $\mathbf{7}$ are here described for the first time as being found in Rubiaceae and the antifungal phenolic glucoside $\mathbf{1}$ is being reported for the first time in literature. Compound 10 was previously isolated from Alibertia myrciifolia. Phenolics $\mathbf{8}$ and $\mathbf{9}$ are here reported for the first time as being found in genus Alibertia. Iridoids $\mathbf{2}$ and 3-5 are in agreement with chemosystematic correlations and botanical occurrence in the Rubiaceae family. This study will contribute significantly to improve knowledge about secondary metabolites and biological activity for one more species from the Brazilian Cerrado.

\section{Acknowledgments}

The authors are grateful to the Fundação de Amparo à Pesquisa do Estado de São Paulo (FAPESP) for financial support and also to the Conselho Nacional de Desenvolvimento Científico e Tecnológico (CNPq) for a fellowship granted to V.C.S.

\section{Supplementary Information}

Supplementary data are available free of charge at http://jbcs.sbq.org.br, as PDF file.

\section{References}

1. Bolzani, V. da S.; Young, M. C. M.; Furlan, M.; Cavalheiro, A. J.; Araújo, A. R.; Silva, D. H. S.; Lopes, M. N.; An. Acad. Bras. Cienc. 1999, 71, 181.

2. Dietrich, S. M. C.; Bucheridge, M.; Tiné, M. A. S.; Young, M. C. M.; Bolzani, V. da S.; Braga, M.; Marques, M. R.; An. Acad. Bras. Cienc. 1998, 70, 726. 
3. Young, M. C. M.; Araújo, A. R.; da Silva, C. A.; Lopes, M. N.; Trevisan, L. M. V.; Bolzani, V. da S.; J. Nat. Prod. 1998, 61, 936.

4. Bolzani, V. da S.; Trevisan, L. M. V.; Izumisawa, C. M.; Gunatilaka, A. A. L.; Kingston D. G. I.; Young, M. C. M.; Phytochemistry 1997, 46, 308.

5. Bolzani, V. da S.; Trevisan, L. M. V.; Izumisawa, C. M.; Young, M. C. M.; J. Braz. Chem. Soc. 1997, 7, 157.

6. Young, M. C. M.; Braga, M. R.; Dietrich, S. M. C.; Gottlieb, H. E.; Trevisan, L. M. V.; Bolzani, V. da S.; Phytochemistry 1992, $31,3433$.

7. Bolzani, V. da S.; Trevisan, L. M. V.; Young, M. C. M.; Phytochemistry 1991, 30, 2089.

8. Luciano, J. H. S.; Lima, M. A. S.; Souza, E. B.; Silveira, E. R.; Biochem. Syst. Ecol. 2004, 32, 1227.

9. Jung, M. J.; Kang, S. S.; Jung, Y. J.; Choi, J. S.; Chem. Pharm. Bull. 2004, 52, 1501.

10. Warashina, T.; Nagatani, Y.; Noro, T. Phytochemistry 2004, $65,2003$.

11. Guarnaccia, R.; Madyastha, K. M.; Tegtmeyer, E.; Coscia, C. J.; Tetrahedron Lett. 1972, 50, 5125.
12. Damtoft, S.; Jensen, R. S.; Nielsen, B. J.; Phytochemistry 1981, 20, 2717.

13. Bianco, A. In Studies in Natural Products Chemistry, Atta-urRahman, ed., Elsevier: Amsterdam, 1990, p. 439.

14. Achenbach, H.; Löwel, M.; Waibel, R.; Gupta, M.; Solis, P.; Planta Med. 1992, 58, 270.

15. Maruta, Y.; Kawabata, J.; Niki, R.; J. Agric. Food Chem. 1995, $43,2592$.

16. Pouchert, C. J.; Behnke, J.; The Aldrich Library of ${ }^{13} \mathrm{C}$ and ${ }^{1} \mathrm{H}$ FT NMR Spectra, Aldrich Chemical Company: Milwakee, 1993.

17. Homans, A. L.; Fuchs, A.; J. Chromatogr. 1970, 51, 327.

18. Rahalison, L.; Hamburger, M.; Monod, M.; Frenk, E.; Hostettmann, K.; Planta Med. 1994, 60, 41.

19. da Silva, V. C.; Silva, G. H.; Bolzani, V. da S.; Lopes, M. N. Ecl. Quim. 2006, 31, 55.

Received: May 23, 2007

Web Release Date: November 14, 2007

FAPESP helped in meeting the publication costs of this article. 


\section{A New Antifungal Phenolic Glycoside Derivative and Iridoids and Lignans from Alibertia sessilis (Vell.) K. Schum. (Rubiaceae)}

\section{Viviane C. da Silva, ${ }^{a}$ Vanderlan da S. Bolzani, ${ }^{a}$ Maria C. M. Young ${ }^{b}$ and Márcia N. Lopes *,a \\ ${ }^{a}$ Departamento de Química Orgânica, Instituto de Química, Universidade Estadual Paulista, CP 355,} 14801-970 Araraquara-SP, Brazil

${ }^{b}$ Seção de Fisiologia e Bioquímica de Plantas, Instituto de Botânica, CP 4005, 01061-970 São Paulo-SP, Brazil

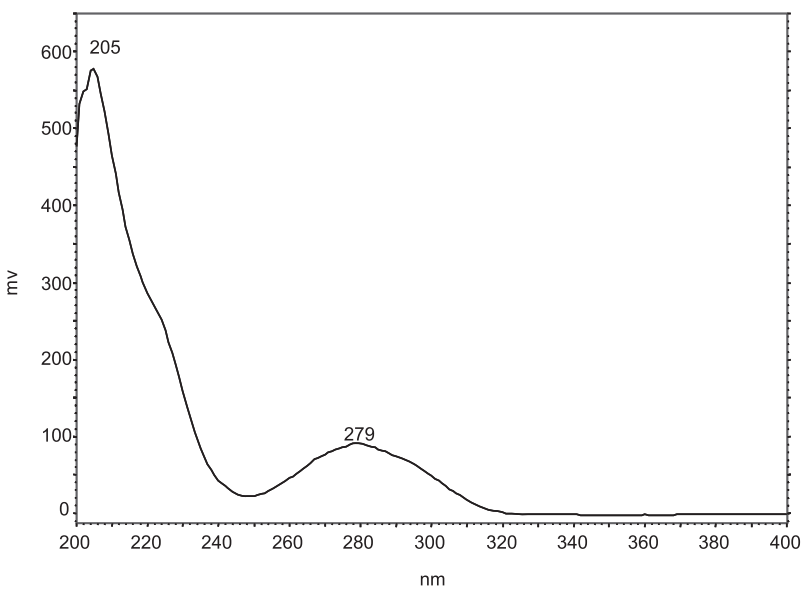

Figure S1. UV spectrum of compound $1(\mathrm{MeOH})$.

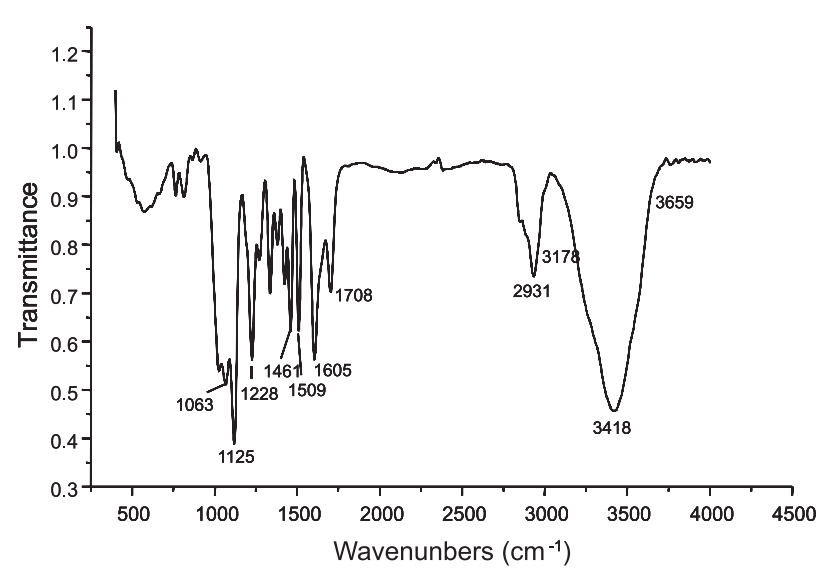

Figure S2. IR spectrum of compound $1(\mathrm{KBr})$. 


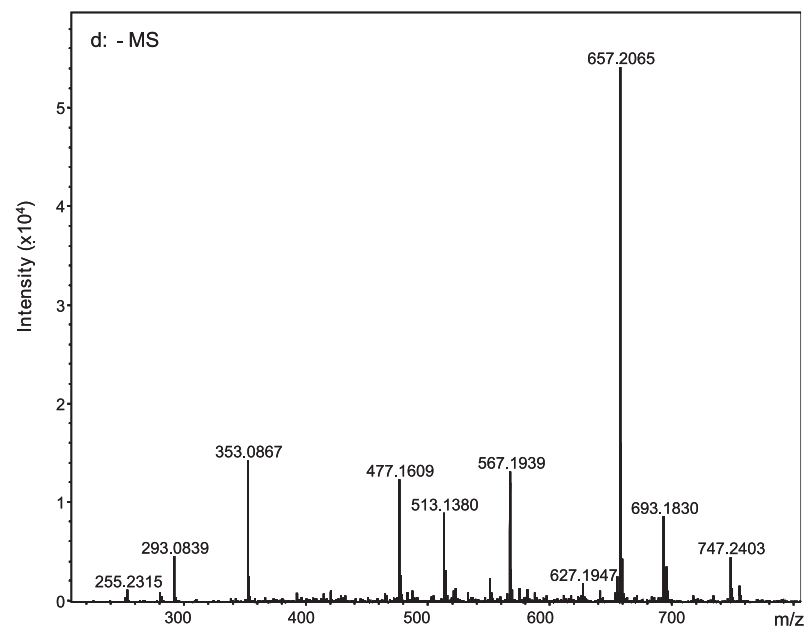

Figure S3. HRESIMS spectrum of compound $\mathbf{1}$ (negative mode).

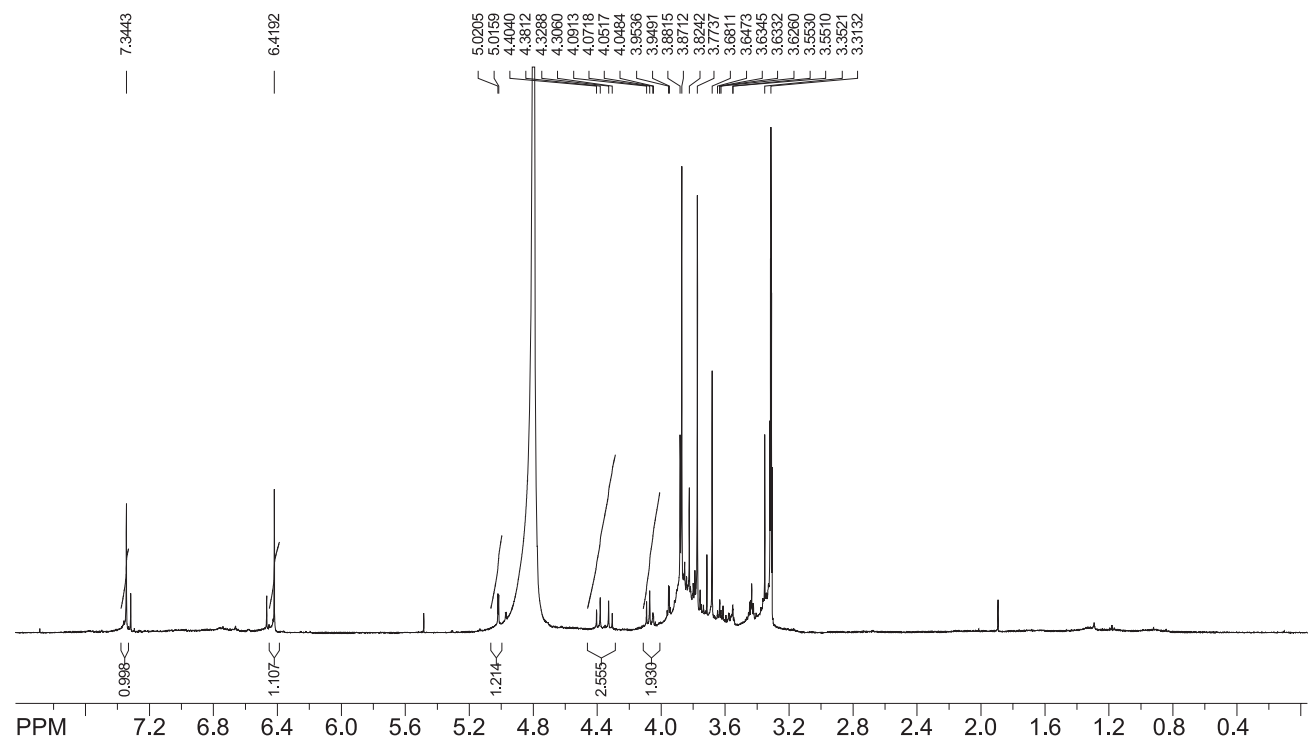

Figure S4. ${ }^{1} \mathrm{H}$ NMR spectrum of compound $\mathbf{1}\left(\mathrm{CD}_{3} \mathrm{OD}, 500 \mathrm{MHz}\right)$. 


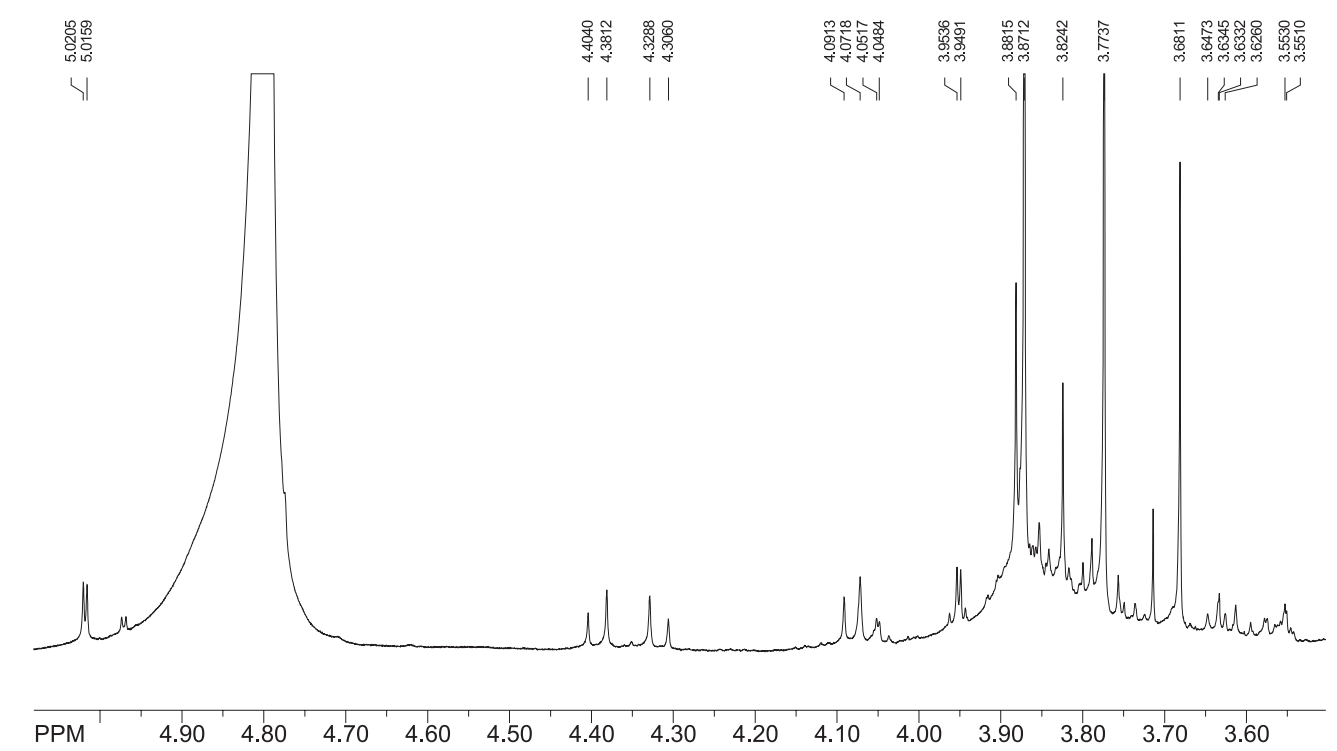

Figure S5. Expansion of ${ }^{1} \mathrm{H}$ NMR spectrum of compound $\mathbf{1}\left(\mathrm{CD}_{3} \mathrm{OD}, 500 \mathrm{MHz}\right)$.

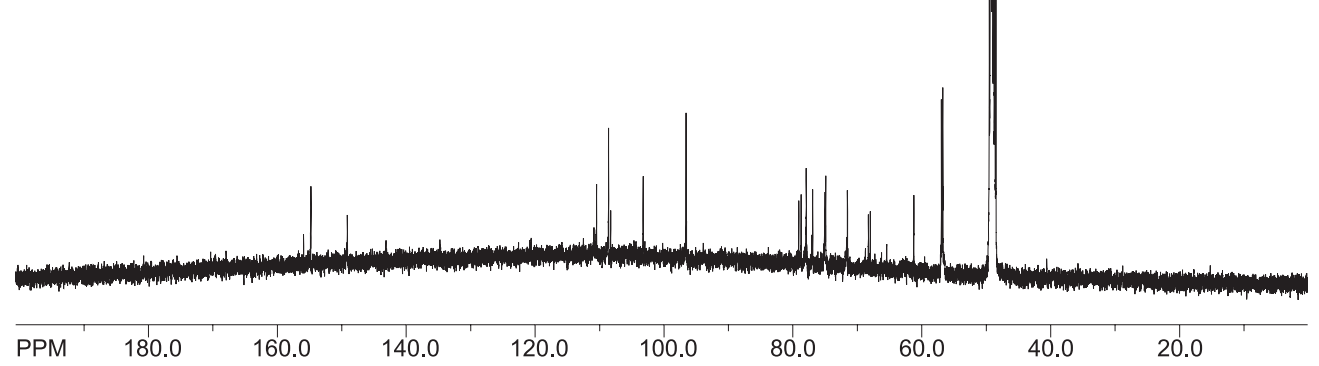

Figure S6. TOCSY spectrum of compound $\mathbf{1}\left(\mathrm{CD}_{3} \mathrm{OD}, 500 \mathrm{MHz}\right)$. 


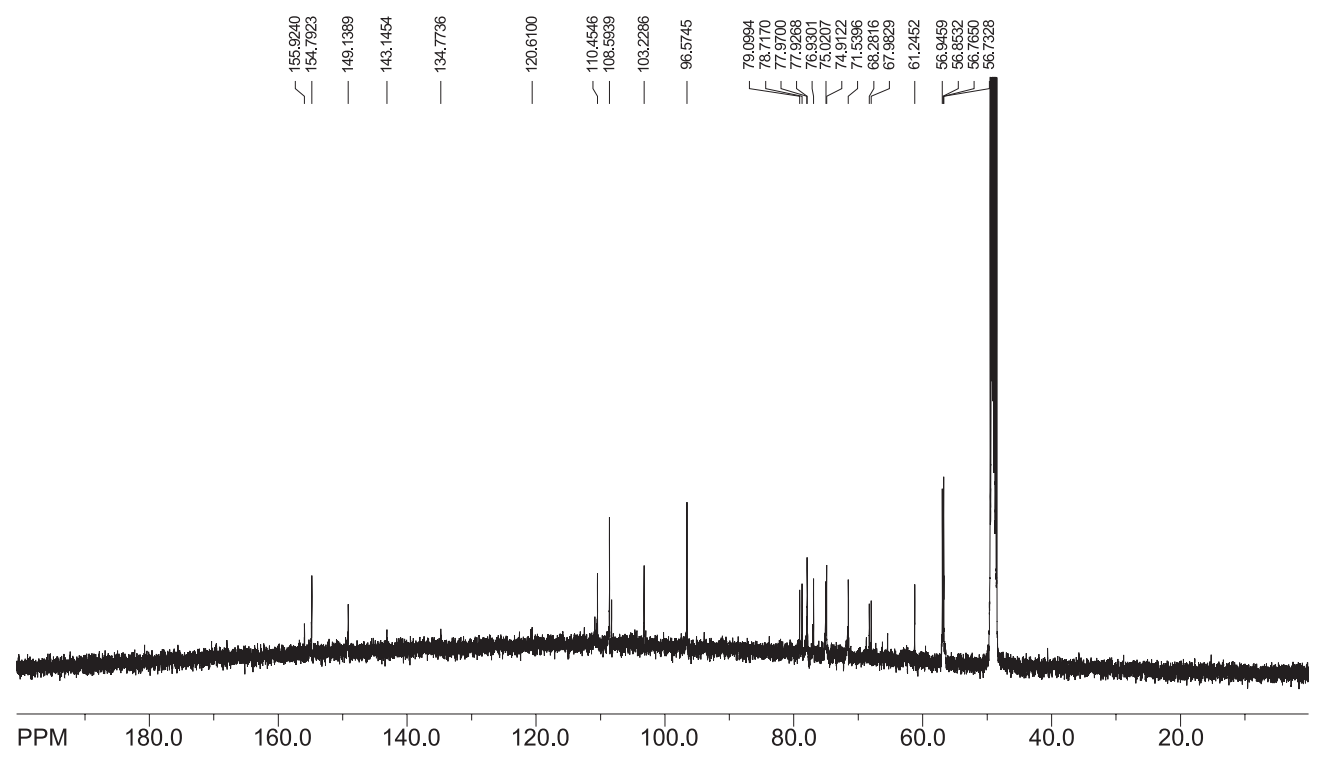

Figure S7. ${ }^{13} \mathrm{C}$ NMR spectrum of compound $\mathbf{1}\left(\mathrm{CD}_{3} \mathrm{OD}, 126 \mathrm{MHz}\right)$.

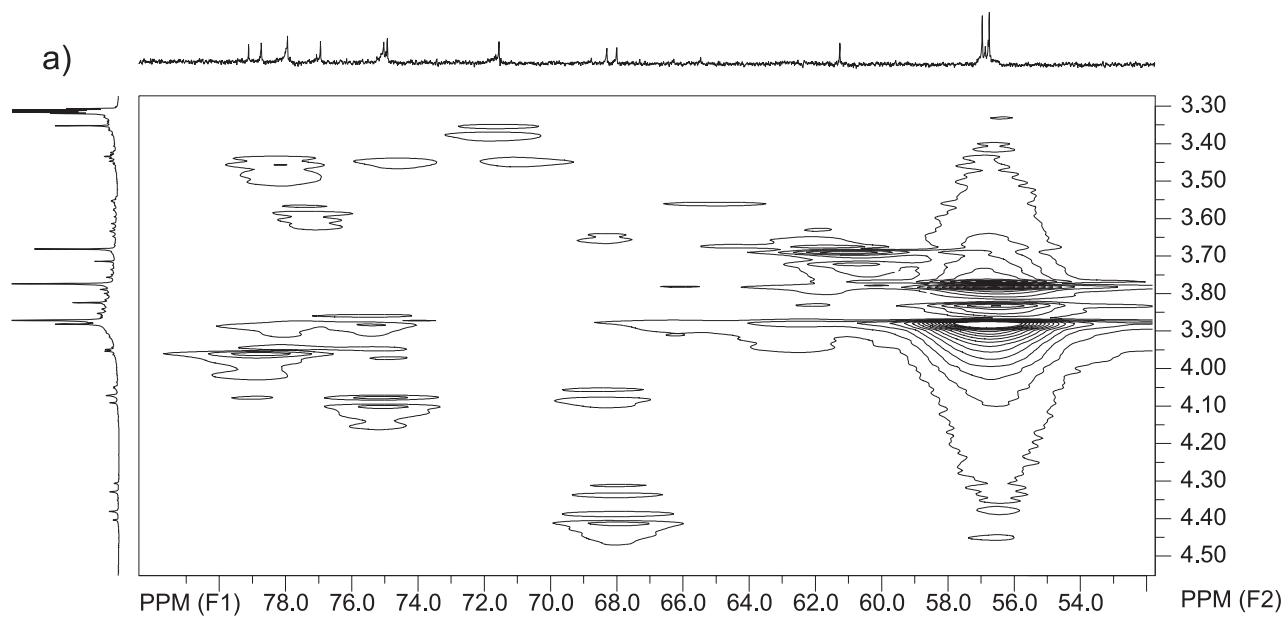

b)

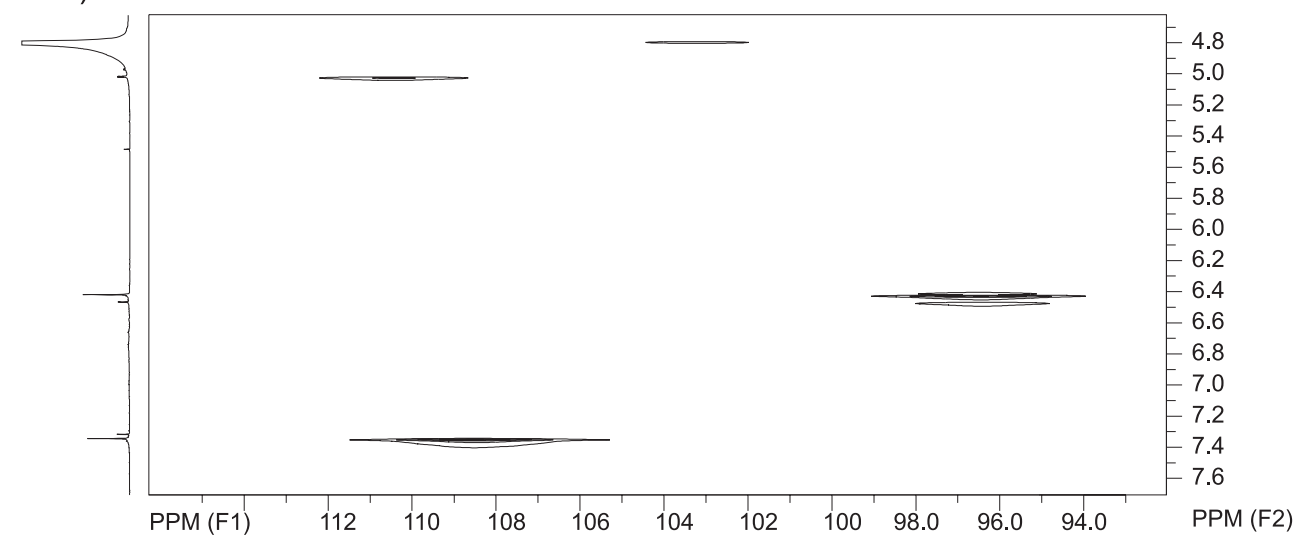

Figure S8. Expansions of the $\mathrm{gHMQC}$ spectrum of compound $\mathbf{1}\left(\mathrm{CD}_{3} \mathrm{OD}, 500 \mathrm{MHz}\right)$. 
a)

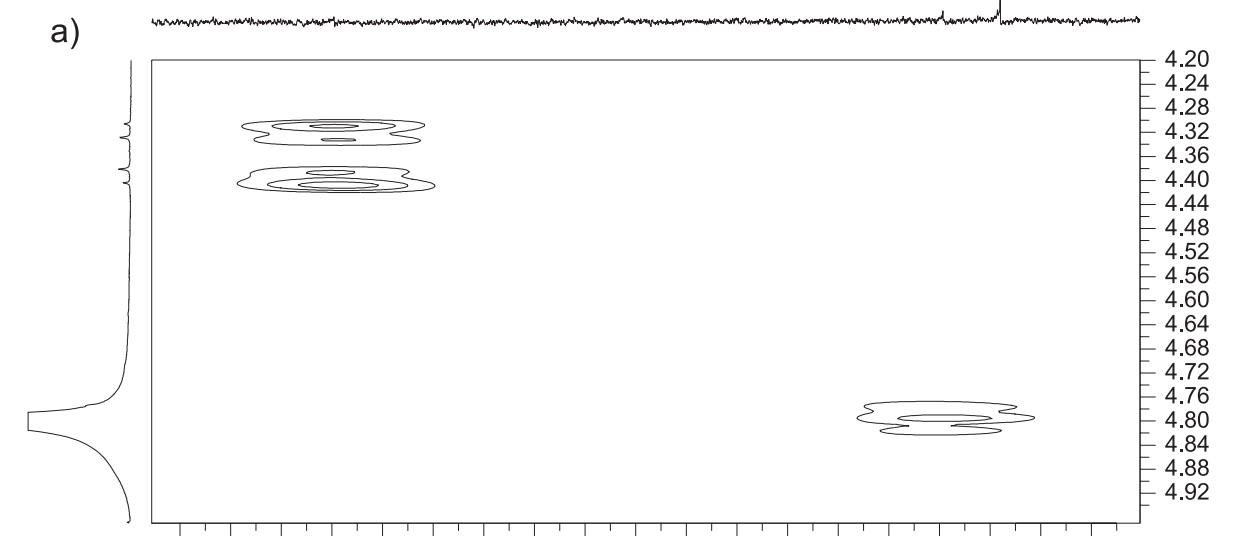

\begin{tabular}{ll|l|l|l|l|l|l|l|l|l|l|l|l|l|l|l|l|}
\hline PPM (F1) & 169 & 168 & 167 & 166 & 165 & 164 & 163 & 162 & 161 & 160 & 159 & 158 & 157 & 156 & 155 & 154 & 153
\end{tabular}

PPM (F2)

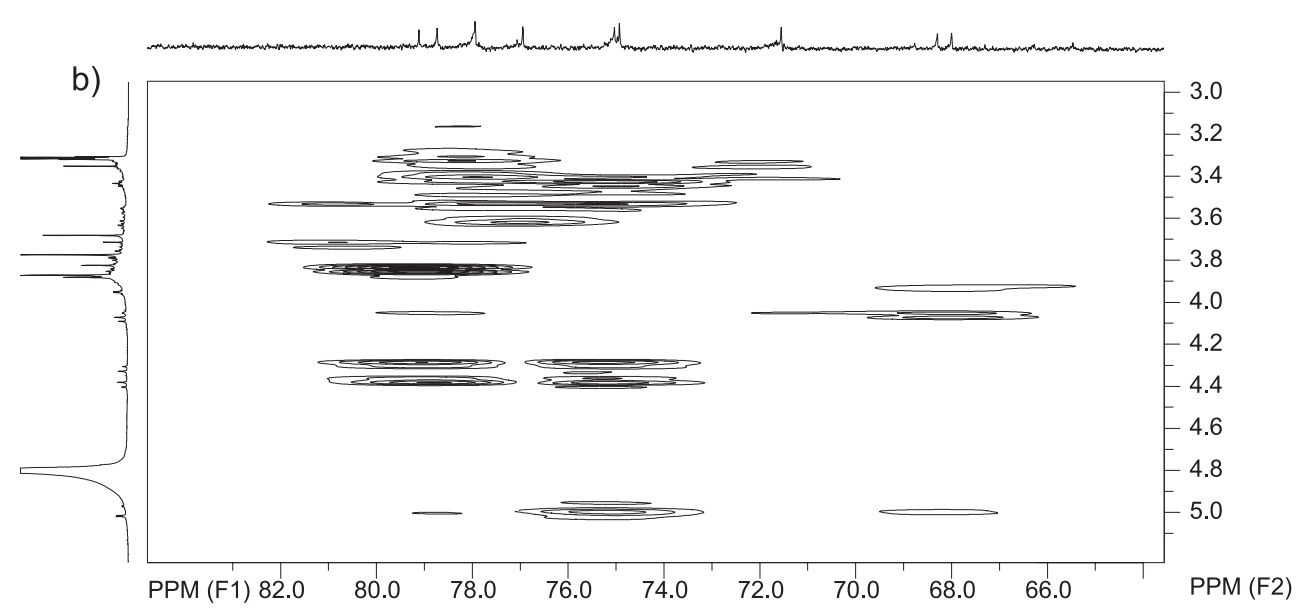

Figure S9. Expansions of the $g \mathrm{HMBC}$ spectrum of compound $\mathbf{1}\left(\mathrm{CD}_{3} \mathrm{OD}, 500 \mathrm{MHz}\right)$. 

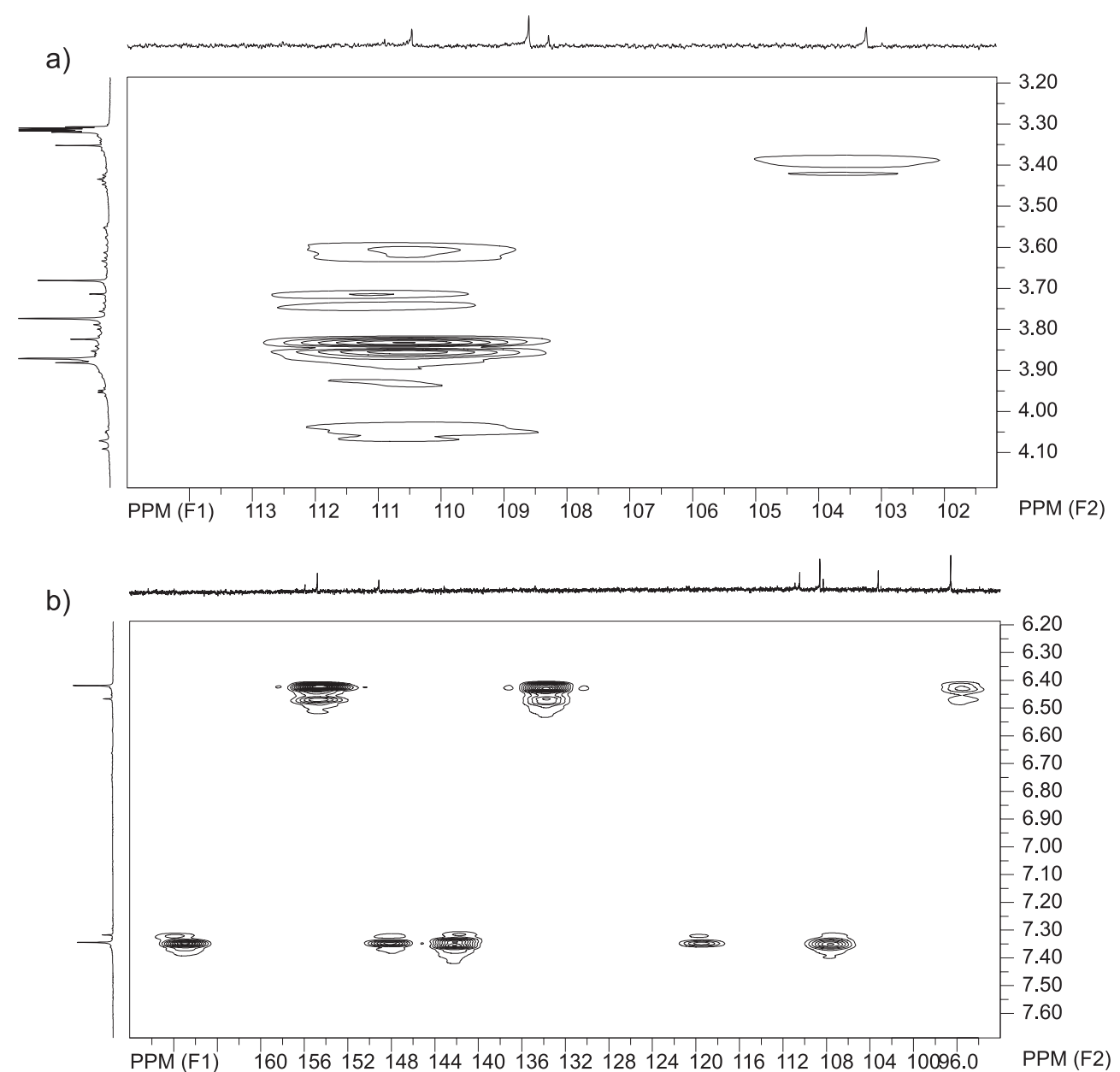

Figure S10. Expansions of the $g \mathrm{HMBC}$ spectrum of compound $\mathbf{1}\left(\mathrm{CD}_{3} \mathrm{OD}, 500 \mathrm{MHz}\right)$. 
Table S1. ${ }^{1} \mathrm{H}$ and ${ }^{13} \mathrm{C}$ NMR data of analogous compounds of $\mathbf{1}$ in literature

\begin{tabular}{|c|c|c|c|c|c|c|}
\hline position & 1 & A & B & $\mathrm{C}$ & $\mathrm{D}$ & $\mathrm{E}$ \\
\hline 1 & 155.9 & 153.1 & 153.6 & 155.9 & 156.0 & \\
\hline 2,6 & $96.5 / 6.41 \mathrm{~s}$ & $\begin{array}{l}103.7 / 6.60 \mathrm{~d}(2.6) \\
110.1 / 6.39 \mathrm{dd}(2.6,8.6)\end{array}$ & $94.0 / 6.26 \mathrm{~s}$ & $96.7 / 6.43 \mathrm{~s}$ & $96.4 / 6.45 \mathrm{~s}$ & \\
\hline 3,5 & 154.7 & $149.9116 .7 / 6.50 \mathrm{~d}(8.6)$ & 153.0 & 154.8 & 154.8 & \\
\hline 4 & 134.7 & 143.4 & 132.4 & 134.8 & 134.6 & \\
\hline 1 ' & $103.2 / 4.79 \mathrm{~d}(7.5)$ & $102.5 / 4.77 \mathrm{~d}(7.2)$ & $99.2 / 4.84 \mathrm{~d}(7.5)$ & $103.3 / 4.79 \mathrm{~d}(8.0)$ & $103.2 / 4.79 \mathrm{~d}(7.3)$ & $104.4 / 4.25 \mathrm{~d}(8.0)$ \\
\hline $2^{\prime}$ & $74.9 / 3.43$ & $79.1 / 3.61$ & $77.2 / 3.50$ & $75.0 / 3.44$ & 74.9 & $75.1 / 3.18$ \\
\hline 3, & $77.9 / 3.52$ & $79.6 / 3.57$ & $75.9 / 3.47$ & $77.9 / 3.44$ & 77.9 & $78.1 / 3.34$ \\
\hline $4^{\prime}$ & $71.5 / 3.34$ & $72.5 / 3.34$ & $70.4 / 3.12$ & $71.5 / 3.35$ & 71.6 & $71.8 / 3.26$ \\
\hline 5 , & $76.9 / 3.60$ & $78.8 / 3.34$ & $77.2 / 3.34$ & $76.9 / 3.56$ & 77.0 & $76.9 / 3.40$ \\
\hline $6^{\prime}$ & $\begin{array}{l}68.2 / 3.63 \mathrm{~d}(10.0) \\
\text { and } 4.06 \mathrm{~d}(10.0)\end{array}$ & $\begin{array}{l}63.4 / 3.65 \mathrm{dd}(12.2,5.4) \\
\text { and } 3.84 \mathrm{dd}(12.2,2.0)\end{array}$ & $60.8 / 3.74 \mathrm{~m}$ & $\begin{array}{l}68.3 / 3.63 \mathrm{dd}(11.0,2.0) \\
\text { and } 4.06 \mathrm{dd}(11.0,6.0)\end{array}$ & 68.8 & $68.6 / 3.63 \mathrm{dd}(10.0,2.0)$ \\
\hline $1 "$ & $110.4 / 5.01 \mathrm{~d}(2.3)$ & $111.3 / 5.50 \mathrm{~s}$ & $108.6 / 5.42 \mathrm{~s}$ & $110.5 / 5.01 \mathrm{~d}(2.0)$ & $110.9 / 4.96 \mathrm{~d}(2.5)$ & $110.8 / 5.05 \mathrm{~d}(2.0)$ \\
\hline $2 "$ & $78.7 / 3.94 \mathrm{~d}(2.3)$ & $79.5 / 4.07 \mathrm{~s}$ & $76.9 / 3.91 \mathrm{~s}$ & $78.6 / 3.96 \mathrm{~d}(2.0)$ & $77.9 / 3.87 \mathrm{~d}(2.5)$ & $78.6 / 4.00 \mathrm{~d}(2.0)$ \\
\hline $3 "$ & 79.0 & 80.0 & 77.5 & 79.0 & 80.5 & 79.1 \\
\hline $4 "$ & $\begin{array}{l}75.0 / 3.85 \mathrm{~m} \text { and } \\
4.08 \mathrm{~d}(9.7)\end{array}$ & $\begin{array}{l}76.1 / 3.90 \mathrm{~m} \text { and } \\
4.29 \mathrm{~d}(9.8)\end{array}$ & $\begin{array}{l}73.9 / 3.85 \mathrm{~d}(9.4) \\
\text { and } 4.11 \mathrm{~d}(9.4)\end{array}$ & $\begin{array}{l}74.9 / 3.86 \mathrm{~d}(10.0) \text { and } \\
4.08 \mathrm{~d}(10.0)\end{array}$ & $\begin{array}{l}74.9 / 3.73 \mathrm{~d}(9.8) \text { and } \\
3.94 \mathrm{~d}(9.8)\end{array}$ & $\begin{array}{l}75.0 / 3.88 \mathrm{~d}(10.0) \\
\text { and } 4.08 \mathrm{~d}(10.0)\end{array}$ \\
\hline $5 "$ & $\begin{array}{l}67.9 / 4.31 \mathrm{~d}(11.4) \\
\text { and } 4.39 \mathrm{~d}(11.4)\end{array}$ & $\begin{array}{l}68.9 / 4.26 \mathrm{~d}(11.5) \text { and } \\
4.42 \mathrm{~d}(11.5)\end{array}$ & $\begin{array}{l}67.1 / 4.22 \mathrm{~d}(11.0) \\
\text { and } 4.27 \mathrm{~d}(11.0)\end{array}$ & $\begin{array}{l}67.6 / 4.31 \mathrm{~d}(11.5) \text { and } \\
4.36 \mathrm{~d}(11.5)\end{array}$ & $65.4 / 3.54 \mathrm{~s}$ & $\begin{array}{l}68.3 / 4.38 \mathrm{~d}(11.5) \\
\text { and } 4.40 \mathrm{~d}(11.5)\end{array}$ \\
\hline 1 '” & 120.6 & 121.8 & 119.1 & 123.3 & & 126.4 \\
\hline 2"”,6", & $108.5 / 7.34 \mathrm{~s}$ & $109.2 / 7.24 \mathrm{~s}$ & $107.1 / 7.15 \mathrm{~s}$ & 132.8 & & $108.4 / 7.35 \mathrm{~s}$ \\
\hline $3 ",, 5 "$ & 149.1 & 149.6 & 147.4 & 114.9 & & 154.5 \\
\hline $4 " ”$ & 143.1 & 142.9 & 140.9 & 165.3 & & 143.9 \\
\hline $\mathrm{C}=\mathrm{O}$ & 167.9 & 168.5 & 165.3 & 167.6 & & 167.4 \\
\hline $\begin{array}{l}3,5- \\
\mathrm{OCH}_{3}\end{array}$ & $56.7 / 3.77$ & $57.0 / 3.71$ & $55.5 / 3.65$ & $56.7 / 3.77$ & $56.7 / 3.81$ & 56.9 \\
\hline $\begin{array}{l}4-\mathrm{OCH}_{3} \\
3, ", 5 \text {,"- } \\
\mathrm{OCH}_{3}\end{array}$ & $\begin{array}{l}61.2 / 3.68 \\
56.9 / 3.87\end{array}$ & $57.7 / 3.84$ & $\begin{array}{l}60.0 / 3.53 \\
56.1 / 3.77\end{array}$ & 61.2 & $61.2 / 3.70$ & 61.2 \\
\hline
\end{tabular}

A $\left(\mathrm{CD}_{3} \mathrm{OD}\right)$ and B (DMSO- $\left.d_{6}\right)$ : ref. 9 - Jung, M. J.; Kang, S. S.; Jung, Y. J.; Choi, J. S.; Chem. Pharm. Bull. 2004, 52, 1501. C, D and E (CD 3 OD): ref. 10 Warashina, T.; Nagatani, Y.; Noro, T. Phytochemistry 2004, 65, 2003.

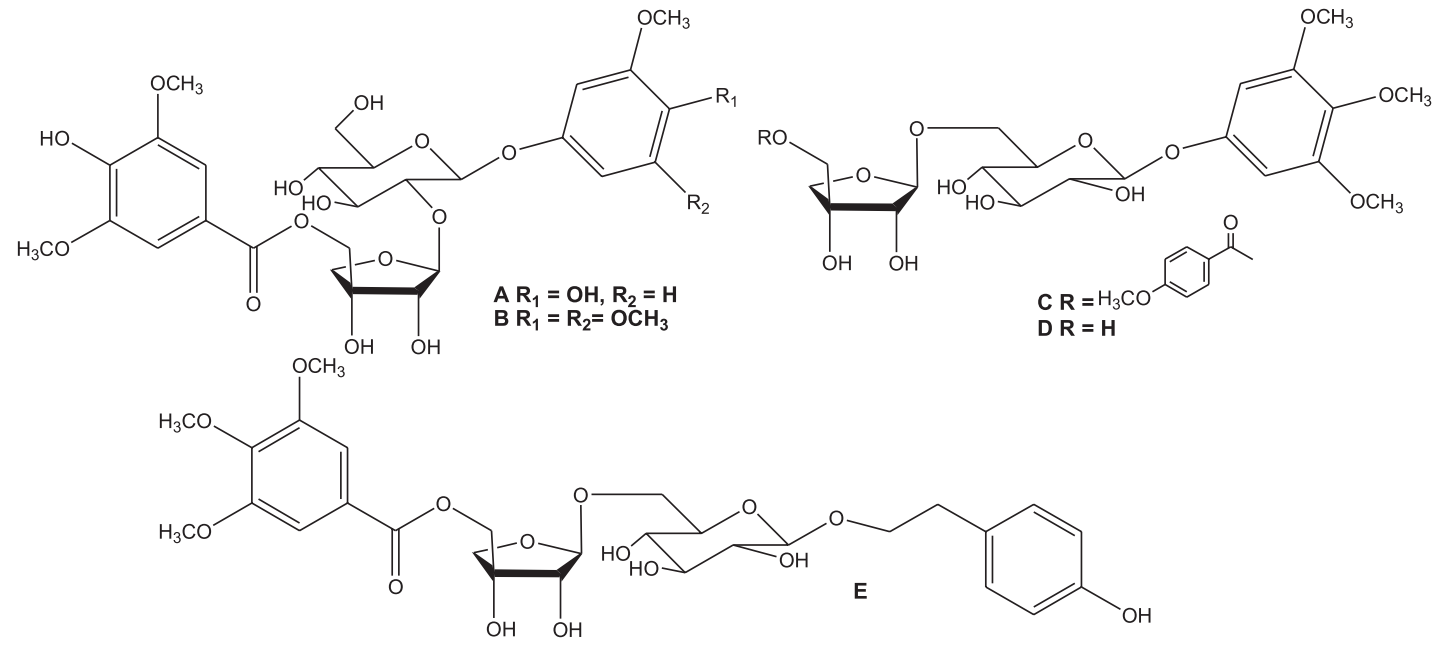

